\title{
Vaginal rhabdomyosarcoma in a patient with Noonan syndrome
}

\author{
S Khan, H McDowell, M Upadhyaya, A Fryer
}

\begin{abstract}
This is the first report of a Noonan syndrome patient who has had a vaginal rhabdomyosarcoma. Recent reports of Noonan syndrome patients with leukaemia have prompted speculation that there may be a slightly increased malignancy risk associated with this syndrome.
\end{abstract}

( $\mathcal{F}$ Med Genet 1995;32:743-745)

Noonan syndrome (NS), as first described, comprises a specific group of dysmorphic features without any demonstrable chromosomal alteration. It can be inherited as an autosomal dominant disorder, a gene locus having recently been mapped to chromosome $12 .^{1}$ The incidence of malignant disease in NS is unknown. It has been suggested that 1 in 2000 cancer patients would have NS if an association is the result of chance alone. ${ }^{2}$ There are a number of reports of patients with NS developing malignant disease which include malignant schwannoma, ${ }^{3}$ phaeochromocytoma, ${ }^{4}$ ganglioneuroma, ${ }^{5}$ and acute lymphoblastic leukaemia. ${ }^{267}$ Some of these malignancy types occur with increased frequency in neurofibromatosis type 1 (NF-1), ${ }^{8-10}$ and there are some NF-1 patients who have a Noonan phenotype (so-called NF 1X, neurofibromatosis/ Noonan syndrome). ${ }^{11}$ Furthermore, patients with Watson syndrome, which is allelic to NF1 , can have some features of NS, notably pulmonary stenosis. ${ }^{12}$ However, none of the reports of NS patients who have had malignancies mentions any clinical features suggestive of $\mathrm{NF}$ 1 or Watson syndrome.

We report a patient with NS who presented with a vaginal rhabdomyosarcoma which is a previously unreported association and we speculate on the nature of the Noonan syndrome gene as a result.

\section{Case report}

A 20 month old girl presented with a three month history of intermittent vaginal bleeding. Four weeks before presentation, the vaginal bleeding became worse and her mother noticed a grape-like mass protruding from the introitus. An abdominal ultrasound scan showed a vaginal mass measuring $1.3 \mathrm{~cm} \times 1.5 \mathrm{~cm} \times 5 \mathrm{~cm}$. CT scanning was consistent with a diagnosis of rhabdomyosarcoma without evidence of metastatic spread. Histology of a biopsy specimen confirmed a botryoid rhabdomyosarcoma. She was treated with chemotherapy to which she had a good response and a repeat biopsy of the vagina after completion of treatment showed no evidence of tumour cells.

At the time of admission, the child was noted to have several dysmorphic features including low set ears, ptosis, hypertelorism, widely spaced nipples, pectus excavatum, and a cardiac murmur owing to mild pulmonary valve stenosis. Her facial appearance is shown in the figure. The features were diagnostic of Noonan syndrome. Neither parent had any signs of NS. She had no cutaneous nor ophthalmological signs of NF-1, although at this age a diagnosis of NF-1 cannot be excluded. Chromosome analysis in the patient was normal. Constitutional and tumour DNA from the patient was analysed for a gross rearrangement within the NF-1 gene using four intragenic polymorphisms in introns $27,{ }^{13} 38,{ }^{14} 39,{ }^{15}$ and $41 .{ }^{16}$ No rearrangement was detected and there was no loss of heterozygosity in the tumour DNA.

\section{Discussion}

Since the original description of Noonan syndrome, there have been occasional reports of NS patients developing malignant disease including malignant schwannoma, phaeochromocytoma, ganglioneuroma, and acute lymphoblastic leukaemia. This is the first report of a child with NS having a vaginal rhabdomyosarcoma.

Rhabdomyosarcoma is the most common soft tissue sarcoma in childhood, constituting $75 \%$ of cases with slight male preponderance. Bladder and vaginal rhabdomyosarcomas are the most common sites in infancy with embryonal and botryoid being the predominant histological subtypes. The age and site in this patient is therefore typical for this tumour and probably represents a chance association in an NS patient.

On the other hand, it is of interest that patients with NF-1, a number of whom have an NS phenotype, have an increased incidence of rhabdomyosarcoma as well as acute leukaemia (though usually myelogenous) and neural crest tumours. These are the types of malignancies that have been reported in NS patients. The presence of a rhabdomyosarcoma in an NS patient could therefore represent a significant association and patients with Noonan syndrome might be prone to malignancies deriving from similar tissues to NF-1 patients. Further evidence for an association between NS and malignancy is required however.

Another possibility is that this patient has $\mathrm{NF}-1$ and has yet to develop any cutaneous manifestations. However, we think it more 

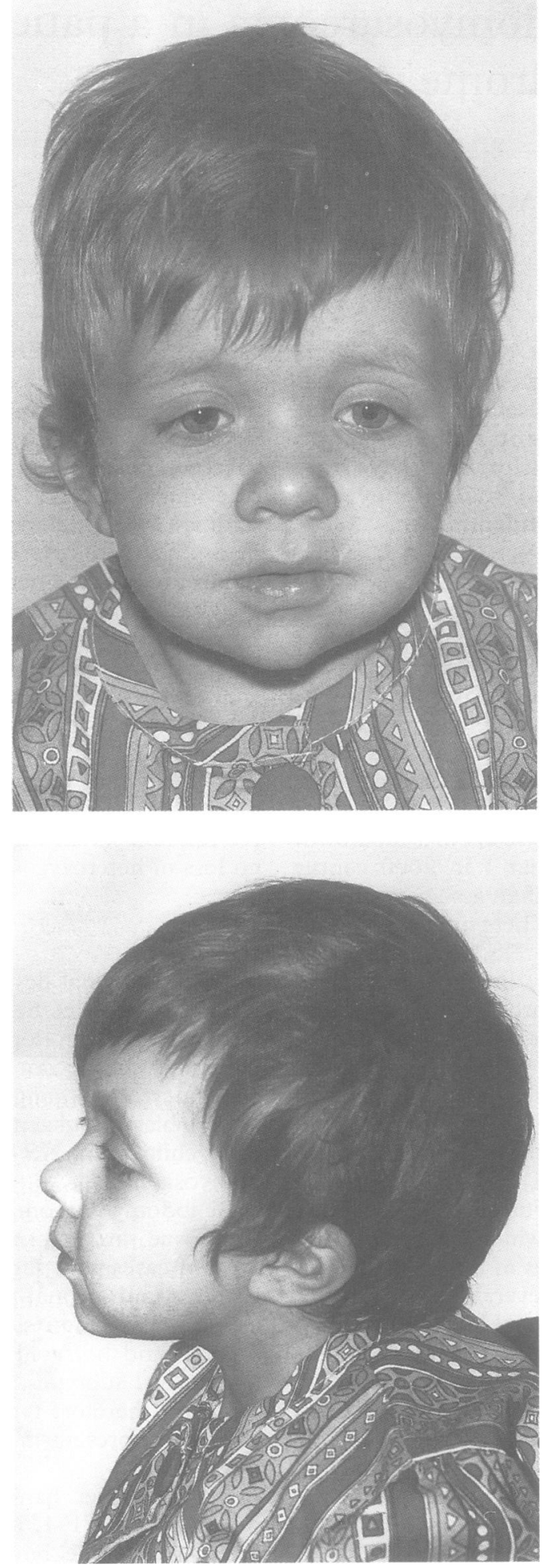

Facial appearance and profile of the proband.

probable that the diagnosis is Noonan syndrome. Some patients with the NF-1-Noonan syndrome phenotype have had large deletions or rearrangements within the NF-1 gene and we have not been able to find any such change in this patient.

If it is subsequently proven that there is a small increased malignancy risk in Noonan syndrome, this may provide a clue to the function of the Noonan gene. There is evidence that the NF-1 gene, neurofibromin, acts as a tumour suppressor, ${ }^{1718}$ although the actual contribution of NF-1 mutations to both NF-1 specific and unrelated sporadic tumours still has to be determined. It is possible that one of the small genes embedded within the NF-1 gene may play a role in addition to the tumour suppressor function of neurofibromin itself. Neurofibromin has extensive sequence homology with a family of GTPase activating protein (GAP) related genes which play an intimate role in the regulation of Ras activity. ${ }^{19}$ Neurofibromin is likely to accelerate the conversion of active $\mathrm{p} 21^{\text {ras }}$ GTP to inactive $\mathrm{p} 21^{\text {ras }}$ GDP. If there are similarities between NF-1 and NS in the type, if not the frequency, of malignancies reported, it is tempting to speculate that the gene responsible for NS could have similar characteristics, that is, have a tumour suppressor function and be involved in a signal transduction pathway.

It is of considerable interest that the recently isolated gene (FGD-1) for Aarskog syndrome, a disorder that can be confused with NS, proves to be a member of the rho/rac GEF (guanine nucleotide exchange factor) family of protooncogenes, which also play a role in cell signal transduction, ${ }^{20}$ and that the initial studies indicate that the clinical phenotype of Aarskog syndrome results from loss of function of the FGD-1 gene. If the NS gene also represented a gene involved in a cell signal transduction pathway, this might be consistent with the observed similarities in phenotype with Aarskog syndrome and NF-1.

No increased incidence in malignancy has been reported in Aarskog syndrome and it is uncertain whether there is an increased risk of malignancy in NS although this and recent reports suggest that this is a possibility. Even if subsequently proven, this increased tumour risk would seem to be small given the absence of malignancies reported in various studies of NS patients, including a recent large survey of 151 patients. ${ }^{21}$

We would like to thank Julie Maynard and Dr Joanne Whittaker for technical assistance in the DNA studies.

1 Jamieson CR, van der Burgt I, Brady AF, et al. Mapping of a gene for Noonan syndrome to the long arm of chromosome 12. Nature Genet 1994;8:357-60.

2 Attard-Montado SP, Kingston JE, Eden T. Noonan's syndrome and acute lymphoblastic leukaemia. Med Pediat Oncol 1994;23:391-2.

3 Kaplan MS, Opitz JM, Gosset FR. Noonan's syndrome: case report with elevated serum alkaline phosphatase levels and malignant schwannoma of the left forearm. $A m \mathcal{f} D i$ Child 1968;116:359-66.

4 Becker CE, Rosen SW, Engelman K. Phaeochromocytoma and hyporesponsiveness to thyrotrophin in a 46XY male with features of Turner pheontype. Ann Intern Med 1969; 70:325-33.

5 Khodadoust A, Paton D. Turner's syndrome in a male. Report of a male with myopia, retinal detachment, cataract and glaucoma. Arch Ophthalmol 1967;77:630-4.

6 Merino AH, Etxeandia IA, Borja MB, Olivera IA. Sindrome Merino AH, Etxeandia IA, Borja MB, Olivera IA. Sindrome
Noonan asociado a leucosis aguda linfoblastica. An Esp

7 Piombo M, Rosanda C, Pasino M, Marasini M, Cerruti P, Comelli A. Acute lymphoblastic leukaemia in Noonan Comelli A. Acute lymphoblastic leukaemia in Noonan syndrome;

8 21:454-5. Bader $\mathrm{J}$, Miller RW. Neurofibromat
leukemia. $₹$ Pediatr 1978;92:925-9.

9 Clark RD, Hutter JJ. Familial neurofibromatosis and juClark RD, Hutter JJ. Familial neurofibromatosis and ju-
venile chronic myelogenous leukemia. Hum Genet 1982; 60:230-2.

0 Shannon KM, O'Connell P, Martin GA, et al. Loss of the normal NF-1 allele from the bone marrow of children with type 1 neurofibromatosis and malignant myeloid disorders. N Engl f Med 1994;330:597-601.

11 Gorlin RJ, Cohen MM Jr, Levin LS. NF 1X neurofibromatosis/Noonan type. In: Syndromes of the head and 
neck. 3rd ed. Oxford: Oxford University Press, 1990: 392-3.

12 Allanson JE, Upadhyaya $\mathrm{M}$, Watson $\mathrm{GH}$, et al. Watson syndrome: is it a subtype of type 1 neurofibromatosis? $f$ 13 Med Genet 1991;28:752-6.

Xu G, Nelson L, O'Connell P, White R. An Alu polymorphism intragenic to the neurofibromatosis type 1 gene (NF1). Nucleic Acids Res 1991;19:3764.

14 Lazaro C, Gaona A, Xu G, Weiss R, Estivill X. A highly informative CA/GT repeat polymorphism in intron 38 of the human neurofibromatosis type 1 (NF1) gene. Hum Genet 1993;92:429-30.

15 Rodenhiser D, Hovland K. A novel Rsa-1 polymorphism within intron 39 of the neurofibromatosis type 1 (NF1) gene. Hum Genet 1995;95:241-2.

16 Shen $M H$, Upadhyaya $M$. Two single base polymorphisms in introns 41 and 16 of the NF-1 gene. Am $\mathcal{F}$ Med Genet (in press).
$17 \mathrm{Xu}$ W, Mulligan LM, Ponder MA, et al. Loss of NF-1 alleles in phaeochromocytomas from patients with type 337-42.

18 Legius E, Marchuk DA, Collins FS, Glover TW. Somatic deletion of the neurofibromatosis type 1 gene in a neurofibrosarcoma supports a tumour suppressor gene hypothesis. Nature Genet 1993;3:122-6.

19 Martin GA, Viskochil D, Bollag G, et al. The Gap-related domain of the neurofibromatosis type 1 gene product interacts with ras p21. Cell 1990;63:843-9.

20 Pasteris NG, Cadle A, Logie LJ, et al. Isolation and characterisation of the faciogenital dysplasia (Aarskog-Scott syndrome) gene: a putative rho/rac guanine nucleotide exchange factor. Cell 1994;79:669-78.

21 Sharland M, Burch M, McKenna WM, Patton MA. A clinical study of Noonan syndrome. Arch Dis Child 1993; 67:178-83. 